\title{
Improvement of wastewater sludge dewatering performance using titanium salt coagulants (TSCs) in combination with magnetic nano-particles: Significance of titanium speciation
}

\author{
Weijun Zhang ${ }^{\mathrm{a},{ }^{*}}$, Zhan Chen ${ }^{\mathrm{b}, \mathrm{d}}$, Bingdi Cao ${ }^{\mathrm{b}}$, Youjing Du ${ }^{\mathrm{b}, \mathrm{c}}$, Caixia Wang ${ }^{\mathrm{b}}$,

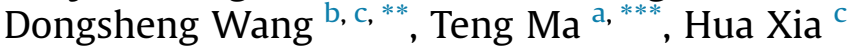 \\ a School of Environmental Studies, China University of Geosciences, Wuhan 430074, Hubei, China \\ b State Key Laboratory of Environmental Aquatic Chemistry, Research Center for Eco-Environmental Sciences, Chinese Academy of Sciences, Beijing 100085, \\ China \\ ${ }^{\mathrm{c}}$ Faculty of Materials Science and Chemistry, China University of Geosciences, Wuhan 430074, Hubei, China \\ d School of Civil Engineering, Inner Mongolia University of Technology, Hohhot 010051, China
}

\section{A R T I C L E I N F O}

\section{Article history:}

Received 16 August 2016

Received in revised form

1 December 2016

Accepted 9 December 2016

Available online 10 December 2016

\section{Keywords:}

Combined conditioning

Dewaterability

EPS

Titanium salt coagulants

Titanium speciation

Wastewater sludge

\begin{abstract}
A B S T R A C T
In this study, the effects of chemical conditioning using titanium salt coagulants (TSCs) of different hydrolysis speciation in combination with magnetic nano-particles on dewatering performance of waste activated sludge were evaluated by means of specific resistance to filtration (SRF) and capillary suction time (CST). The morphological and extracellular polymeric substances (EPS) properties under chemical conditioning were investigated in detail to understand the reaction mechanisms involved. The results showed that the TSC with basicity of 0.5 performed better in improving sludge dewatering performance than other TSCs. Sludge floc formed by $\mathrm{TSC}_{0.5}$ treatment was characterized by larger floc size and higher floc strength than that conditioned by other TSCs. EPS compression and densification were the major mechanisms of sludge conditioning, and $\mathrm{TSC}_{0.5}$ had better performance in compressing EPS structure. In addition, reduction of soluble EPS concentration, especially protein-like substances contributed to improvement of sludge filterability under conditioning. Furthermore, addition of $\mathrm{Fe}_{2} \mathrm{O}_{3}$ nanoparticles could further improve dewatering performance and decrease compressibility of sludge system by acting as skeleton builders and enhancing floc strength. The sludge particles aggregation efficiency was effectively improved with addition of nano- $\mathrm{Fe}_{2} \mathrm{O}_{3}$. They also were able to bind with protein-like substance in EPS component, which might contribute to promotion of sludge filterability.
\end{abstract}

() 2016 Elsevier Ltd. All rights reserved.

\section{Introduction}

The management of wastewater sludge, now often referred to as biosolids, accounts for a major portion of the cost of the wastewater treatment process and represents significant technical challenges. High-performance dewatering has been proven to be an efficient

\footnotetext{
* Corresponding author. School of Environmental Studies, China University of Geosciences, Wuhan 430074, Hubei, China.

** Corresponding author. State Key Laboratory of Environmental Aquatic Chemistry, Research Center for Eco-Environmental Sciences, Chinese Academy of Sciences, Beijing 100085, China.

*** Corresponding author. School of Environmental Studies, China University of Geosciences, Wuhan 430074, Hubei, China.

E-mail addresses: zhwj_1986@126.com (W. Zhang), wgds@rcees.ac.cn
} (D. Wang), mateng@cug.edu.cn (T. Ma). method to reduce sludge volume, cutting transportation and disposal cost (Neyens et al., 2004). Generally, the moisture in activated sludge can be classified into free water (about 70\%), interfacial water (about 20\%) and bound water (about 10\%) (Vaxelaire and Cézac, 2004). Except for the sludge characteristics, the dewatering efficiency was mainly dependent on the selection of device and chemical conditioning process.

The extracellular polymeric substances (EPS) accounted for 60-80\% of sludge biomass (Liu and Fang, 2003). Many studies have demonstrated that EPS properties had important influence on sludge settling, flocculation and dewatering properties. Again, EPS content also greatly affected the charge property and floc stability (Mikkelsen and Keiding, 2002). Houghton et al. (2001) found that there existed a certain EPS mass at which the sludge dewaterability reach the maximum (Houghton et al., 2001). Higgins and Novak 
(1997) demonstrated that the sludge dewaterability was mainly affected by the ratio of protein and polysaccharide. Proteins exhibited more significant influence on sludge dewaterability than polysaccharide, high protein/polysaccharide was always detrimental to dewatering process. This observation was in agreement with Murtgy and Novak's findings (1999). Recently, Li and Yang (2007) suggested that the spatial distribution and chemical compostion of EPS had more significant effects on sludge dewatering property, and sludge dewatering performance was mainly dependent on content of loosely-bound EPS (LB-EPS) rather than that of tightly bound EPS (TB-EPS). Furhter, Yu et al. (2008) demonstrated that soluble EPS also played an important role in sludge dewatering process. Zhang et al. (2015a) suggested that change in concentration and compostion of soluble EPS fraction caused fluctuation of sludge dewatering behavior with time.

Prior to dewatering, chemicals were always dosed to improve sludge dewatering performance (called chemical conditioning). Addition of traditional chemical conditioners (inorganic salt coagulants and organic polymers) can agglomerate fine sludge colloids to form large flocs through charge neutralization and bridging, which can be more easily separated from the water (Niu et al., 2013; Zhang et al., 2014a). $\mathrm{TiCl}_{4}$ is novel environmentally friendly inorganic coagulants and has attracted much attention in water and wastewater treatment (Shon et al., 2007; Zhao et al., 2011). It was found that $\mathrm{TiCl}_{4}$ performed well in removing particles and natural organic matters (NOMs) in drinking water treatment. And it has many advantages of larger floc, low dosage and more settleable than traditional iron and aluminum salts coagulation etc. (Shon et al., 2009a, 2009b). Due to its strongly hydrolytic and acidic properties, addition of $\mathrm{TiCl}_{4}$ would cause serious acidification of water. Poly-titanium salt coagulants (TSC) were prepared with pre-hydrolyzed process which can abate this problem. TSC exhibited better hydrolytic stability and coagulation performance for NOM and turbidity removal (Tomaszewska et al., 2004). In addition, the residuals produced from titanium salt coagulation can be converted into $\mathrm{TiO}_{2}$ materials through high-temperature calcination (Shon et al., 2009a, 2009b; Kim et al., 2011), which is known to be an environmentally friendly photocatalyst. Nano materials, especially nano oxides have exhibited excellent physical and chemical properties and have many advantages over traditional adsorption materials, so they attracted much attention in recent years (Liang et al., 2004). Compared with traditional flocculation and adsorption materials, nano- $\mathrm{Fe}_{2} \mathrm{O}_{3}$ had better adsorption and flocculation performance for humic acid and protein-like substances (Wang et al., 2009a,b). In addition, nano- $\mathrm{Fe}_{2} \mathrm{O}_{3}$ particles were able to act as skeleton builders and enhance sludge floc strength, so they were selected as a co-conditioner of TSCs to decrease compressibility and improve dewaterability of wastewater sludge in this work."

So far, few investigations have focused on effects of sludge conditioning using titanium salt coagulants (TSC) in combination with nano- $\mathrm{Fe}_{2} \mathrm{O}_{3}$. Therefore, the aims of this study are to: (1) test the conditioning efficiency of TSC with different speciations; (2) understand the variations in morphological and EPS properties (distribution and composition) of sludge flocs to unravel the underlying mechanism involved; (3) investigate the conditioning efficiency and changes in floc properties under conditioning using TSC in combination with nano- $\mathrm{Fe}_{2} \mathrm{O}_{3}$; (4) provide a novel sludge pre-conditioning technique prior to dewatering process.

\section{Material and methods}

\subsection{Source and properties of wastewater sludge}

Surplus sludge was sampled from sludge return line of membrane bioreactor (MBR) in Northern brook wastewater treatment plant of Beijing. Now the daily wastewater treatment capacity is 200 thousands ton. The wastewater is reclaimed with combined process of MBR and ozonation. The sludge properties were given in Table 1 . The volatile suspended solid (VSS), total suspended solid (TSS) and moisture content were measured according to standard methods (Apha, 1998).

\subsection{Chemical reagents}

All of reagents used in this study are of chemical grade. Spherical $\alpha$-nanoFe $\mathrm{O}_{3}$ was purchased from Sinopharm group in China $(99.5 \%$ metals basis).

\subsection{Experimental procedures}

\subsubsection{Preparation of different titanium salt coagulants}

Slow alkali spotting was used to prepare the polytitanium chloride (TSC) as follow. Firstly, $\mathrm{TiCl}_{4}$ solution (20\%, wt/wt) was put into the ice-bath. $5 \mathrm{~mol} / \mathrm{L} \mathrm{NaOH}$ solution was dropped in the $\mathrm{TiCl}_{4}$ solution with slow rate under vigorous agitation supplied by magnetic stirrer. Three TSCs were synthesized by controlling the molar ratio of $\mathrm{OH}^{-} / \mathrm{Ti}^{4+}$ (B value) under $0.5\left(\mathrm{TSC}_{0.5}\right), 1.5\left(\mathrm{TSC}_{1.5}\right)$ and 2.5 (TSC 2.5 ) respectively.

\subsubsection{Sludge conditioning procedures}

Sludge samples were reacted with coagulants by using magnetic stirrer, the reacted procedure can be described as follows: a rapid mix period for $2 \mathrm{~min}$ at $400 \mathrm{rpm}$ followed by a slow mix period for $8 \mathrm{~min}$ at $40 \mathrm{rpm}$. The titanium salt coagulants with different speciation were added under agitation using graduated pipette. For combined conditioning, the $\mathrm{Fe}_{2} \mathrm{O}_{3}$ was dosed prior to titanium salt coagulants addition.

\subsection{Analytical methods}

\subsubsection{Sudge dewaterability assessment}

2.4.1.1. SRF and compressibility. Specific resistance to filtration (SRF) is widely used to evaluate sludge dewatering performance in filtration process. It can be obtained by equation (1):

$r=\frac{2 P A^{2} b}{\mu \omega}$

Where $\mathrm{P}\left(\mathrm{Kg} \cdot \mathrm{m}^{-2}\right)$ denotes pressure, $\mathrm{A}\left(\mathrm{m}^{2}\right)$ is filtration area, $\mu$ $\left(\mathrm{Kg} \cdot \mathrm{s} \cdot \mathrm{m}^{-2}\right)$ is kinetic viscosity, $\omega\left(\mathrm{kg} \cdot \mathrm{m}^{-3}\right)$ denotes dry solid weight per unit volume sludge on the filtrate media, $b$ is slope of filtration equation-dt/dV $=\mathrm{bV}+\mathrm{a}$, and $\mathrm{t}(\mathrm{s})$ is time, $\mathrm{V}\left(\mathrm{m}^{3}\right)$ denotes volume of filtrate. The raw and conditioned waste sludge was poured into a Buchner funnel with a $0.45 \mu \mathrm{m}$ cellulose acetate membrane to filter under a pressure of $0.6 \mathrm{MPa}$ of vacuum filtration. Volume of filtrate was recorded every 10 s before surface cracking was observed.

The sludge cake compressibility measures the ability to compact the sludge when a normal pressure is applied (Qi et al., 2011). In practice sludge compressibility is often quantified as the slope of a $\log$-log plot of the SRF versus the applied differential pressure. The coefficient of compressibility (s) is obtained by fitting data to Eq. (1)(Zhao and Bache, 2001).

$\frac{\mathrm{SRF}_{1}}{S R F_{2}}=\left(\frac{\mathrm{P}_{1}}{\mathrm{P}_{2}}\right)^{S}$

In which $\mathrm{P}_{1}$ and $\mathrm{P}_{2}$ are two different filtration pressures ( $\left.\mathrm{Pa}\right)$, $S R F_{1}$ and $S_{R F}$ are measured at $P_{1}$ and $P_{2}$, respectively. 
Table 1

Characteristics of wastewater sludge.

\begin{tabular}{|c|c|c|c|c|c|c|c|}
\hline Indicator & Moisture content (\%) & $\mathrm{pH}$ & VSS/TSS & $\operatorname{CST}(\mathrm{s})$ & $\mathrm{d}_{0.5}(\mu \mathrm{m})$ & Zeta potential $(\mathrm{mV})$ & $\mathrm{DOC}(\mathrm{mg} / \mathrm{L})$ \\
\hline Value & 98.18 & 7.5 & 0.75 & 86.2 & 56.623 & -14.2 & 24.096 \\
\hline
\end{tabular}

2.4.1.2. Capillary suction time (CST). Sludge dewaterability was measured with a portable CST instrument (CST 304B, Triton, UK) equipped with an $18 \mathrm{~mm}$ diameter funnel and Whatman No. 17 chromatography-grade paper. The CST values were normalized by dividing them by the initial TSS concentration and then expressed in units of seconds per liter per gram TSS. The sludge settleability was characterized by the sludge volume index (SVI), which is defined as the volume (in $\mathrm{mL}$ ) occupied by $1 \mathrm{~g}$ of sludge after 30 min of settling in a $1 \mathrm{~L}$ cylinder.

\subsubsection{Characterization of sludge properties}

2.4.2.1. Characterization of floc morphology. Malvern Mastersizer is capable of providing rapid, reproducible results of the particle size distribution of digested sludge, with no adverse shear effect on the floc structure. Floc size, fractal dimension $\left(D_{f}\right)$, recovery factor $\left(R_{f}\right)$ and strength factor $\left(\mathrm{S}_{\mathrm{f}}\right)$ were studied to compare the properties of floc. A higher $D_{f}$ normally corresponds to a more compact interior floc structure(Wang et al., 2009a,b).

For independently scattering aggregates, the relationship among I, $\mathrm{Q}$ and the fractal dimension $\mathrm{D}_{\mathrm{f}}$ can be represented by Eq. (1):

$I \propto Q^{D_{F}}$

The relationship shown in Eq. (2) indicates the determination of $D_{f}$, which can be given by the slope of $\log$ I versus $\log Q$ by fitting a straight line.

An increased value of $S_{f}$ indicates flocs that are better able to withstand shear and thus should be considered stronger than a floc with lower value. Likewise an increase in the recovery factor shows flocs that have better regrowth after high shear (Jarvis et al., 2005).

Floc breakage and regrowth experiments were carried out and repeated three times as follows: a regular coagulation process without sedimentation) followed by a breakage phase at $400 \mathrm{rpm}$ for $1 \mathrm{~min}$ and a regrowth phase at $40 \mathrm{rpm}$ for $10 \mathrm{~min}$. A small-angle light scattering instrument (Malvern Mastersizer2000, Malvern, UK) was used to measure dynamic floc size and fractal dimension $\left(D_{f}\right)$ as the coagulation process proceeded (Liu et al., 2013). The $R_{f}$ and $\mathrm{S}_{\mathrm{f}}$ may be calculated as follows (Jarvis et al., 2005):

$S_{f}=\frac{d_{a}}{d_{b}} \times 100 \%$

$R_{f}=\frac{d_{c}-d_{b}}{d_{a}-d_{b}} \times 100 \%$

Where $d_{a}$ is the average floc size of the plateau before breakage, $d_{b}$ is the floc size after the floc breakage period, and $d_{c}$ is the floc size after regrowth to the new plateau.

2.4.2.2. Field emission scanning electron microscope (FE-SEM) analysis. The sludge samples were made by freeze-drying treatment under vacuum at $-60^{\circ} \mathrm{C}$ for $72 \mathrm{~h}$. With samples freeze-dried, FESEM analysis was used by HITACHI SU8020 FE-SEM.

\subsubsection{EPS characterization}

2.4.2.3.1. Extraction of EPS. Firstly, raw sludge sample was settled down at $3000 \mathrm{~g}$ for $10 \mathrm{~min}$, and the supernatant was collected as SEPS. The sludge pellet in the tube was resuspended into $50 \mathrm{ml}$ of $0.05 \% \mathrm{NaCl}$, sonicated at $20 \mathrm{kHz}$ for $20 \mathrm{~min}$, shaken horizontally at $150 \mathrm{rpm}$ for $10 \mathrm{~min}$ in shaker, sonicated again for an additional $2 \mathrm{~min}$. The liquor was centrifuged at $5000 \mathrm{~g}$ for $10 \mathrm{~min}$ to separate solids and supernatant. The collected supernatant was regarded as the LB-EPS. And then the suspension was transferred and heated for $30 \mathrm{~min}$ in water-bath at the temperature of $60{ }^{\circ} \mathrm{C}$. The extracted solution was centrifuged at $5000 \mathrm{~g}$ for $10 \mathrm{~min}$ and separated as bound EPS (Hongwei et al., 2008). The particulates present in the two EPS fractions were removed with polytetrafluoroethylene membranes with a pore size of $0.45 \mu \mathrm{m}$ prior to organic analysis.

\subsection{Analysis of EPS}

2.4.2.3.2.1. 3-DEEM

Three-dimensional excitation emission matrix (3-DEEM) spectra were measured on a F-4500 fluorescence spectrophotometer (Hitachi, Japan) with an excitation range from 200 to $400 \mathrm{~nm}$ at $10 \mathrm{~nm}$ sampling intervals and an emission range from 280 to $500 \mathrm{~nm}$ at $10 \mathrm{~nm}$ sampling interval. The spectra were recorded at a scan rate of $12,000 \mathrm{~nm} / \mathrm{min}$, using excitation and emission slit bandwidths of $10 \mathrm{~nm}$. Each scan had 37 emission and 27 excitation wavelengths (Sheng and Yu, 2006).

2.4.2.3.2.2. High performance size-expulsion chromatography (HPSEC)

Molecular weight (MW) was determined by a Waters liquid chromatography system that consisted of a Waters 2487 Dual $\lambda$ Absorbance Detector, Waters 1525 pump system. A Shodex KW 802.5 gel chromatography column (Shoko, Japan) was used for organic materials separation. The mobile phase, namely Milli $Q$ water buffered with $5 \mathrm{mM}$ phosphate to $\mathrm{pH} 6.8$, and $0.01 \mathrm{M} \mathrm{NaCl}$ was filtered through a $0.22 \mu \mathrm{m}$ membrane, and then degassed for 30 min by means of ultra-sonication before use. A $600 \mu \mathrm{L}$ sample was injected at a flow rate of $0.8 \mathrm{ml} \mathrm{min}{ }^{-1}$. Polystyrene sulfonate standards (Sigma-Aldrich, USA) of MWs 1.8-32 kDa were used for apparent molecular weight (AMW) calibration (Wang et al., 2010; Chow et al., 2008).

\subsubsection{Other indicators}

$\mathrm{pH}$ was measured by $\mathrm{pH}$ meter (pHS-3C, Shanghai, China). Zeta potential measurements were performed on a Zetasizer (Zetasizer, 2000; Malvern, UK). Other sludge parameters, including TSS, volatile suspended solids (VSS), TOC was determined with a TOC analyzer (Teledyne Tekmar, USA).

\section{Results and discussion}

\subsection{Effects of titanium salt coagulants dose on sludge properties}

\subsubsection{Effects of titanium salt coagulants dose on sludge} dewaterability

Effects of sludge conditioning using TSCs with different speciation on SRF and cake moisture content (CMC) was presented in Fig. 1. It can be seen that SRF decreased and reached the equilibrium with increasing the dosage of TSCs from $0.001 \mathrm{~g} / \mathrm{gTSS}$ to $0.005 \mathrm{~g} /$ gTSS, and the conditioning efficiency followed the order: $\mathrm{TSC}_{0.5}>\mathrm{TSC}_{1.5}>\mathrm{TSC}_{0}\left(\mathrm{TiCl}_{4}\right)>\mathrm{TSC}_{2.5}$. On the other hand, change in CMC showed a similar pattern with SRF under TSCs conditioning. $\mathrm{TSC}_{0.5}$ exhibited a better performance in reducing SRF and CMC 

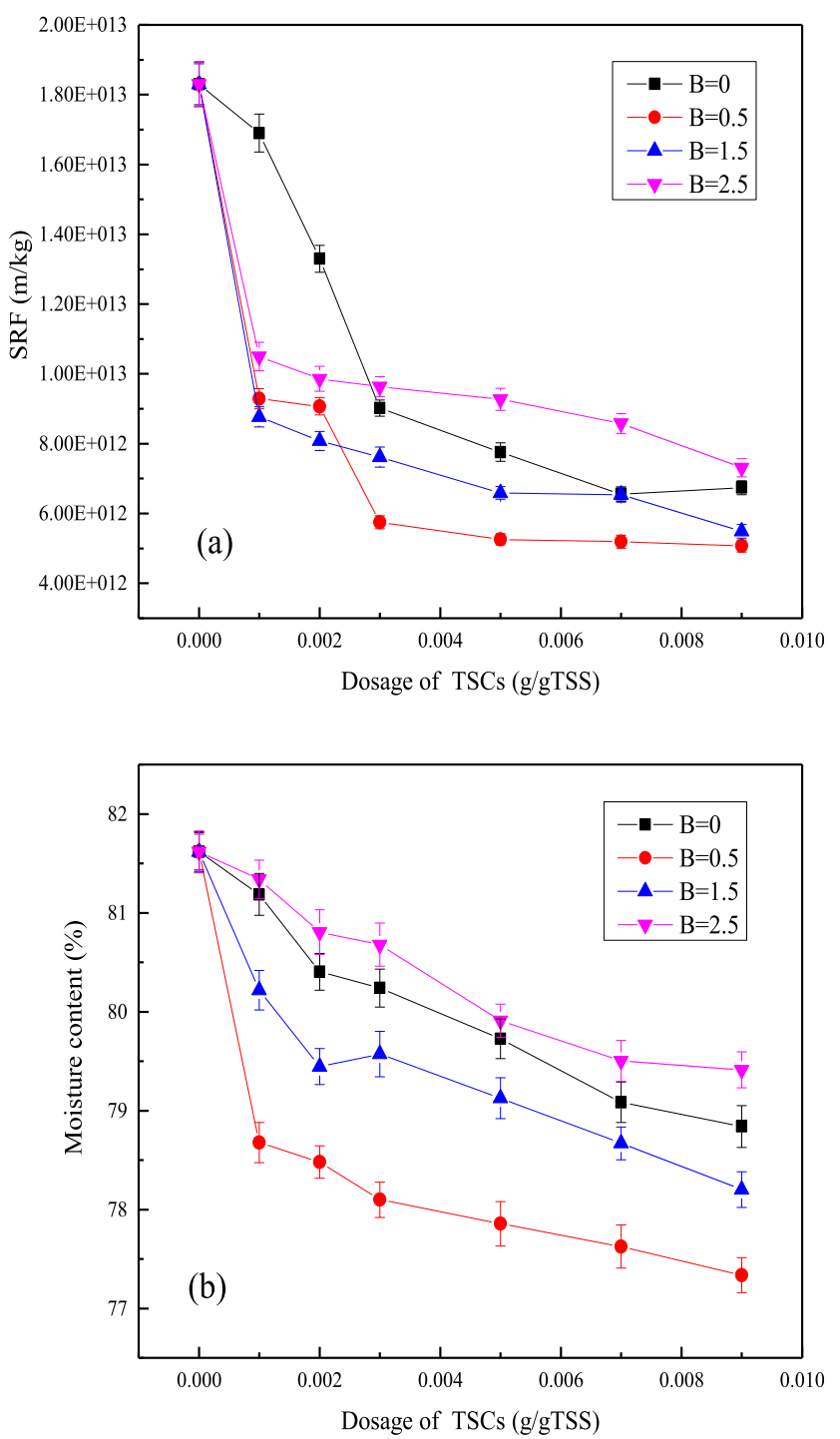

Fig. 1. Effects of TSCs dosages on the sludge dewaterability: (a) SRF; (b) cake moisture content.

than other TSCs. It can be concluded that pre-hydrolysis was able to effectively improve the on sludge conditioning efficiency of TSCs, and moderate pre-hydrolyzed TSC $\left(\mathrm{TSC}_{0.5}\right.$ ) was more effective than other TSCs ( $\mathrm{Ti}^{4+}$ and high-polymeric species) in improving sludge dewatering performance. Zhao et al. (2013) suggested that degree of polymerization reached the maximum by raising the $\mathrm{B}$ value to 1.5 , while it would decrease due to decomposition of hydrolyzed products under alkaline conditions. It should be noted that sludge $\mathrm{pH}$ was sharply decreased to 2-3 after addition of $\mathrm{TiCl}_{4}$, which might affect the subsequent treatment and disposal of sludge, such as composting, land use and incineration. In comparison to $\mathrm{TiCl}_{4}$, release of $\mathrm{H}^{+}$was greatly alleviated under pre-hydrolyzed titanium conditioning because of their higher hydrolytic stability.

Activated sludge contains large amounts of organic materials, such as EPS and microbial cells. All these materials are generally negatively charged, which might prevent sludge particles aggregation, making sludge system highly compressible. Sludge compressibility is an indication of strength of sludge system. Effects of sludge treatment using different TSC on sludge compressibility coefficient were depicted in Fig. 2. The compressibility coefficient of raw sludge was 1.72 , and it was decreased after chemical

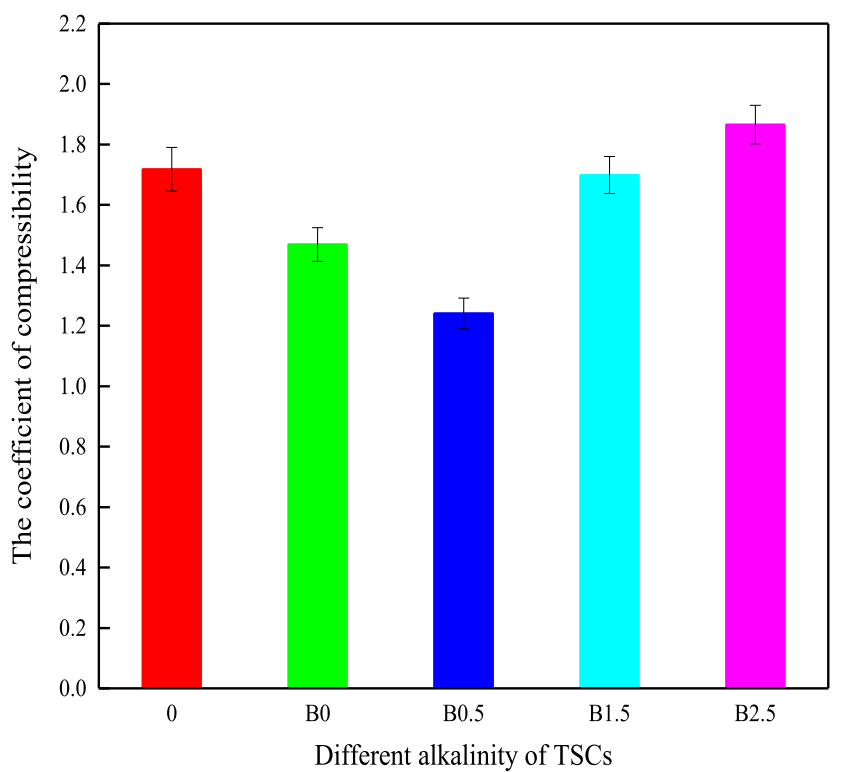

Fig. 2. Effects of TSCs with different speciation on sludge compressibility.

conditioning with all TSCs. Sludge conditioned with $\mathrm{TSC}_{0.5}$ showed the lowest compressibility, which was in agreement with the change in SRF.

\subsubsection{Change in floc morphology under chemical conditioning with different TSCS}

The variations of average floc size $\left(\mathrm{d}_{0.5}\right)$ and $\mathrm{D}_{\mathrm{f}}$ under chemical conditioning with different TSCs can be found in Fig. 3. The changes in sludge floc size conditioned with different TSCs varied greatly. The sludge floc size gradually increased at the beginning of flocculation and it reached the equilibrium after the end of slow stirring process, which confirmed the dynamic balance of sludge flocs breaking and aggregation (Biggs et al., 2001). Sludge floc size sharply decreased when the speed reached $400 \mathrm{rpm} / \mathrm{min}$, then it gradually increased under the mixing speed of $40 \mathrm{rpm} / \mathrm{min}$. The sludge floc size under $\mathrm{TSC}_{1.5}$ and $\mathrm{TSC}_{0}$ treatment was larger than that with $\mathrm{TSC}_{0.5}$ and $\mathrm{TSC}_{2.5}$, which led to a better settling performance. It increased from $90.05,72.31,73.34$ and $62.02 \mu \mathrm{m}$ to 140.07 , $130.87 \mu \mathrm{m}, 80.96$ and $73.24 \mu \mathrm{m}$ after TSCs addition of TSC $1.5, \mathrm{TSC}_{0}$, $\mathrm{TSC}_{0.5}$ and $\mathrm{TSC}_{2.5}$, respectively. Table 2 showed the strength and recovery factors of sludge floc formed by chemical conditioning with different TSCs, revealing that flocs treated with $\mathrm{TSC}_{0.5}$ was more resistant to break under mechanical shearing. Additionally, as it can be seen from Fig. 3 (b), $D_{F}$ of sludge flocs were increased under $\mathrm{TSC}_{0.5}$ and $\mathrm{TSC}_{2.5}$ treatment, while it decreased with $\mathrm{TSC}_{0.5}$ and $\mathrm{TSC}_{1.5}$. When $\mathrm{B}$ value of TSC was 0.5 , the $\mathrm{D}_{\mathrm{F}}$ reached the maximum and reached 2.10. This suggested that the better sludge dewatering performance may due to its higher strength of floc structure and denser aggregates.

\subsubsection{Effects of sludge conditioning with different TSCS on EPS distribution and composition}

3.1.3.1. EPS distribution. As mentioned above, EPS is the most important constituents of sludge system and is believed to affect the sludge settling, flocculation and dewatering behaviors. Therefore, the variations in EPS distribution and composition were investigated. As depicted in Fig. 4, concentrations of all sludge EPS fractions were obviously decreased with under chemical conditioning using different TSCs, indicating that sludge floc strength was enhanced. This observation is in agreement with the report of 

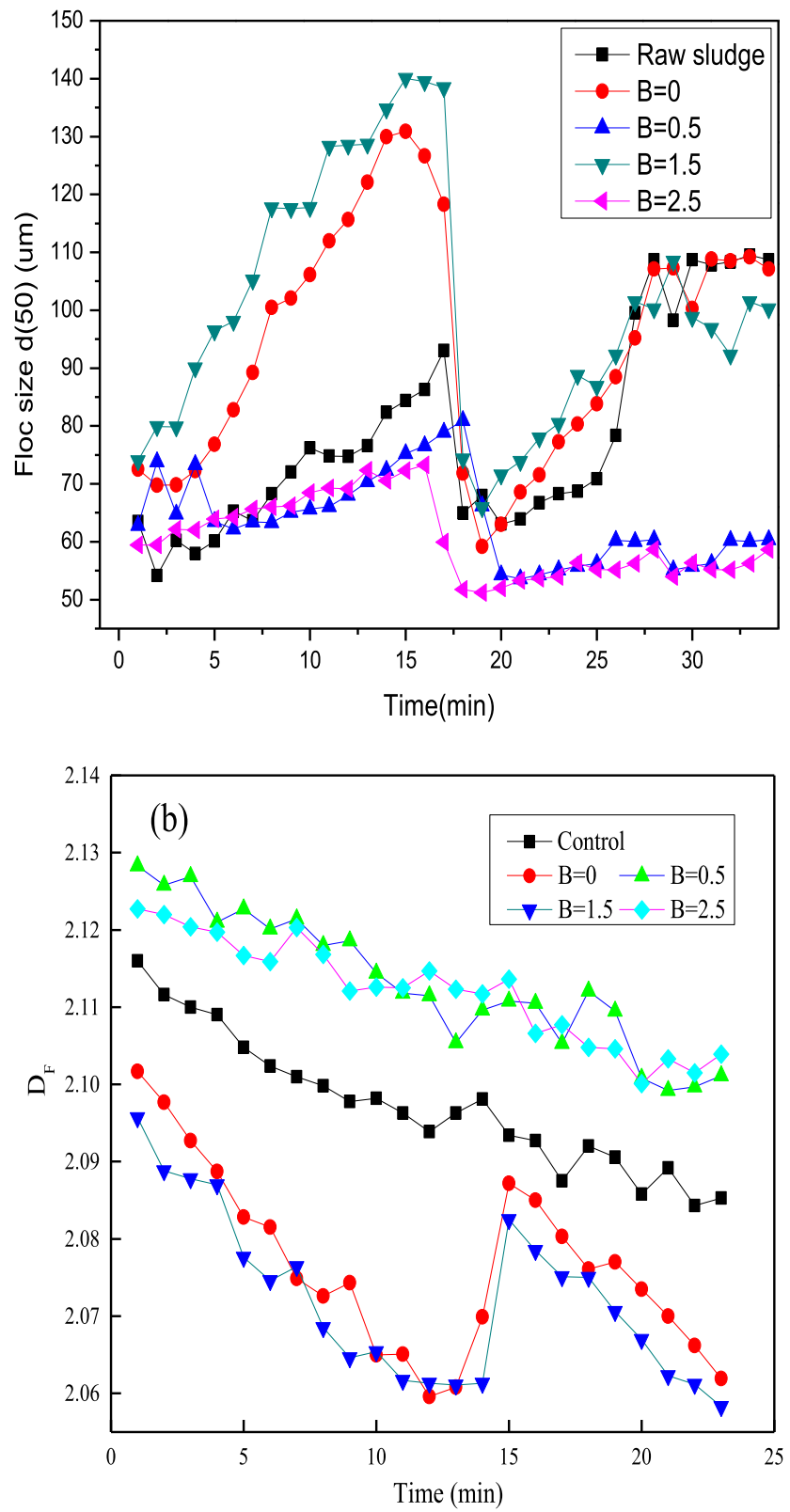

Fig. 3. Changes in particle size and fractal dimension of sludge flocs with time under chemical conditioning with TSCs.

Table 2

Strength and recovery factors of sludge floc formed with different TSCs.

\begin{tabular}{lll}
\hline Sludge floc & $\mathrm{R}_{\mathrm{f}}(\%)$ & $\mathrm{S}_{\mathrm{f}}(\%)$ \\
\hline Raw & 2.13 & 0.773 \\
TSC $_{0}$ & 0.669 & 0.515 \\
TSC $_{0.5}$ & 0.534 & 0.899 \\
TSC $_{1.5}$ & 0.447 & 0.518 \\
TSC $_{2.5}$ & 0.257 & 0.742 \\
\hline
\end{tabular}

Zhang et al., who found that EPS compress was the major mechanism of sludge conditioning with inorganic coagulants. In addition, it is worthy to note that $\mathrm{TSC}_{0.5}$ had better performance in compressing EPS structure than other TSCs. Organic concentrations sharply decreased from $1.20,0.81,13.26 \mathrm{mgDOC} / \mathrm{gTSS}$ to $0.65,0.5$ and $7.84 \mathrm{mgDOC} / \mathrm{gTSS}$ in SEPS, LB-EPS and TB-EPS fractions
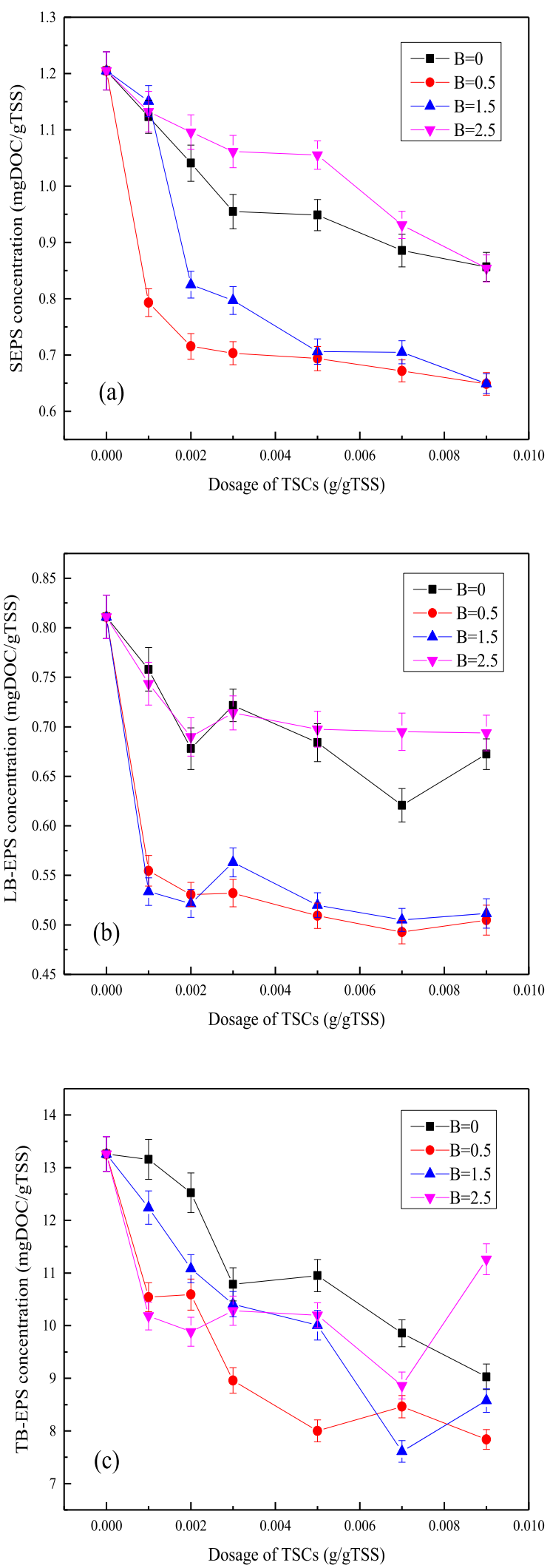

Fig. 4. Effects of TSCs dosages on concentrations of different EPS fractions: (a) SEPS, (b) LB-EPS and (c) TB-EPS. 
respectively. In general, low extractable total EPS was always related to high sludge floc strength, which was in accordance with experimental results described above. In addition, acidification was observed after addition of TSCs, it was more evident for high dose of TSCs with lower basicity (see in Table S1). As mentioned above, this would affect the consequent sludge treatment and disposal. It was reported that acidic treatment significantly change the chemical structure of organic matters (e.g. protein-likes) and this might lead to the dissolution of sludge EPS and cations (e.g. $\mathrm{Ca}^{2+}, \mathrm{Mg}^{2+}, \mathrm{Al}^{3+}$ and $\mathrm{Fe}^{3+}$, etc.)(Zhang et al., 2015b). Many studies have demonstrated that sludge filtration property was mainly dependent on properties of soluble EPS fraction, and the high content of protein in soluble EPS was always detrimental to sludge filterability (Zhang et al., 2014b, 2015c, 2015d). In addition, reduction of soluble EPS concentration contributed to improvement of sludge filterability, it was obvious that $\mathrm{TSC}_{0.5}$ was more effective in removal of soluble EPS fraction. In order to get insights into the changes in chemical composition, EPS samples were characterized by EEM and HPSEC later.

\subsubsection{Chemical composition of EPS}

3.1.3.2.1. 3D-EEM analysis. 3D-EEM is an advanced analytical tool with high sensitivity and selectivity. It has been widely used in characterization of natural organic matters (NOMs) with fluorescent response, such as proteins and humic substances (Henderson et al., 2009). As depicted in Fig. S2 (see in supporting information), four fluorescent peaks were detected in SEPS and LB-EPS fractions of raw sludge: Peak A ( $\left.\lambda_{\text {ex }} / \mathrm{em}=280 / 335\right)$ - tryptophan-like protein, Peak B $(\lambda$ ex/em $=230 / 330)$ - aromatic protein, Peaks C $(\lambda$ ex/ $\mathrm{em}=275 / 455)$ - fulvic acid and Peak $\mathrm{D}\left(\lambda_{\mathrm{ex} / \mathrm{em}}=350 / 420\right)$ - humic acid; while only two peaks (A and $B$ ) related to proteins were observed in TB-EPS (Booksh et al., 2004). It can be seen from Table 3 that fluorescent intensities of four peaks were reduced after sludge conditioning with different TSCs. Fluorescent intensities of four peaks were reduced after sludge conditioning with different TSCs. The variations of peak intensities related to aromatic protein-like and tryptophan protein-like substances were also coincident with the changes of sludge dewaterability. As shown in Fig. S2 in Supporting information, the fluorescent intensities of peaks $A$ and $B$ in SEPS, LB-EPS and TB-EPS correlated well with CST values. This result indicated that sludge dewatering performance was more dependent on protein-like substances in LB-EPS and TB-EPS fractions, which was consistent with the report of Li et al. (2016). Especially, peak B in SEPS and LB-EPS was almost undetectable after

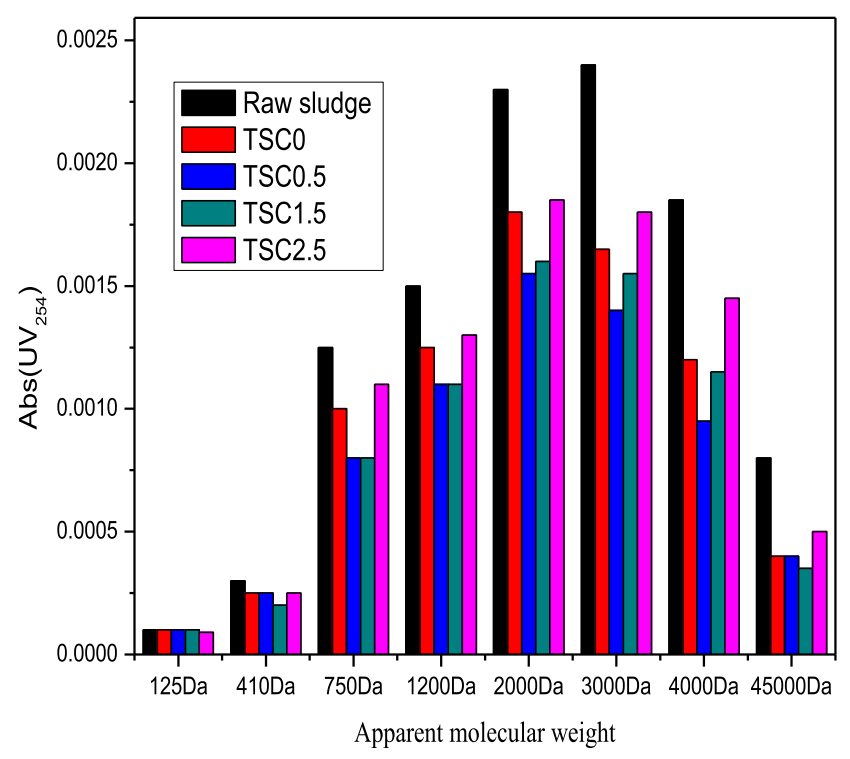

Fig. 5. Influence of TSCs conditioning on organic matters with different molecular weights in SEPS (Samples were diluted by 10 times).

$\mathrm{TSC}_{0.5}$ treatment, revealing that it is very easy to bind with proteinlike substances. In our previous studies, it was found that sludge dewatering was strongly dependent on concentration of proteinlike substances in SEPS (Zhang et al., 2015c, 2015d). Therefore, proteins removal was favored for sludge dewatering property improvement under TSCs conditioning.

As depicted in Fig. 5 and Fig. S4 (see in supporting information), eight MW peaks can be detected in SEPS fraction: 125Da, 400Da, 700Da, 1200Da, 3000 Da, 4000 Da, 25,000 Da and 45,000 Da. Lyko et al. (2007) suggested that three main molar mass fractions can be distinguished: high MW organic compounds ( $>5000 \mathrm{Da}$ ) mainly composed of proteins and polysaccharides, mid-MW compounds (1000-5000 Da) composed of humic substances and organic matter of low MW ( $<1000 \mathrm{Da})$, composed of organic building blocks. Each intensity of MW peak significantly weakened after TSCs treatment, especially the high molecular weight peaks, which was confirmed by the absence of MW peak on 25,000 Da. In addition, $\mathrm{TSC}_{0.5}$ was more effective on removal of mid and high MW organic matters in comparison to the other TSCs, which were always associated with protein-like substances. Our previous studies

Table 3

Effects of different alkalinity of TSC on fluorescent intensities of EPS.

\begin{tabular}{|c|c|c|c|c|c|}
\hline & \multirow[t]{2}{*}{ Different alkalinity of TSC } & \multirow{2}{*}{$\frac{\text { Tryptopha protein }}{\lambda \text { ex/em }(280 / 335)}$} & \multirow{2}{*}{$\frac{\text { Aromatic protein }}{\lambda \text { ex/em }(230 / 330)}$} & \multirow{2}{*}{$\frac{\text { Fulvic acid }}{\lambda \operatorname{ex} / \operatorname{em}(275 / 455)}$} & \multirow{2}{*}{$\frac{\text { Humic acid }}{\lambda \operatorname{ex} / \mathrm{em}(350 / 420)}$} \\
\hline & & & & & \\
\hline \multirow[t]{5}{*}{ SEPS } & control & 126.1 & 105.8 & 28.94 & 19.66 \\
\hline & $\mathrm{B}=0$ & 74.33 & 58.01 & 27.36 & 22.64 \\
\hline & $\mathrm{B}=0.5$ & 52.74 & 27.91 & 14.11 & 17.32 \\
\hline & $\mathrm{B}=1.5$ & 66.15 & 47.76 & 26.39 & 17.86 \\
\hline & $\mathrm{B}=2.5$ & 123.4 & 119.5 & 30.12 & 34.04 \\
\hline \multirow[t]{5}{*}{ LB-EPS } & control & 122.8 & 99.66 & 46.76 & 18.5 \\
\hline & $\mathrm{B}=0$ & 121.6 & 88.8 & 35.5 & 17.88 \\
\hline & $\mathrm{B}=0.5$ & 70.3 & 33.59 & 16.64 & 12.54 \\
\hline & $\mathrm{B}=1.5$ & 68.01 & 34.62 & 21.42 & 14.13 \\
\hline & $\mathrm{B}=2.5$ & 102.9 & 110.7 & 23.76 & 24.67 \\
\hline \multirow[t]{5}{*}{ TB-EPS } & control & 1007 & 568.3 & 65.06 & 29.05 \\
\hline & $\mathrm{B}=0$ & 908.5 & 468.6 & 148.9 & 31.42 \\
\hline & $\mathrm{B}=0.5$ & 573.2 & 334.8 & 46.75 & 34.09 \\
\hline & $\mathrm{B}=1.5$ & 724.4 & 529.1 & 35.59 & 9.082 \\
\hline & $\mathrm{B}=2.5$ & 975.3 & 543.7 & 77.54 & 30.38 \\
\hline
\end{tabular}

\footnotetext{
a SEPS samples were diluted by 10 times; LB-EPS and TB-EPS samples were diluted by 50 times.
} 
suggested that the high content of protein in SEPS was always detrimental to sludge filterability (Zhang et al., 2014b, 2015c, 2015d). Yu et al. (2008) also found that the sludge dewaterability correlated well with proteins content in the supernatant and LBEPS rather than that in TB-EPS fraction. As mentioned above, HPSEC analysis further confirmed that the waste activated sludge dewatering performance was enhanced by $\mathrm{TSC}_{0.5}$ treatment was mainly related to its higher binding capacity with protein-like substances.

\subsection{Effects of composite nano $\mathrm{Fe}_{2} \mathrm{O}_{3}$ and $\mathrm{TSC}_{0.5}$ treatment on activated sludge properties}

\subsubsection{Effects of composite nano $\mathrm{Fe}_{2} \mathrm{O}_{3}$ and $\mathrm{TSC}_{0.5}$ treatment on sludge filtration dewaterability}

The evolutions of sludge SRFs under composite nano $\mathrm{Fe}_{2} \mathrm{O}_{3}$ and $\mathrm{TSC}_{0.5}$ conditioning at respective filtration suction pressure of 0.05 and $0.07 \mathrm{MPa}$ can be seen in Fig. 6 (a). It should be noted that the SRF decreased firstly and then increased with the dosage of nano$\mathrm{Fe}_{2} \mathrm{O}_{3}$ addition. Moreover, it reached the minimum when the dosage was $0.03 \mathrm{~g} / \mathrm{gTSS}$, which was decreased by $56 \%$. The sludge floc compressibility with composite treatment was depicted in Fig. 6 (b). It also achieved the minimum when the dosage of nano $\mathrm{Fe}_{2} \mathrm{O}_{3}$ was $0.03 \mathrm{~g} / \mathrm{gTSS}$, which decreased from 1.24 to 0.91 . This was in agreement with the previous result of SRF determination.

\subsubsection{Change in floc morphology under chemical conditioning using TSCs in combination with nano- $\mathrm{Fe}_{2} \mathrm{O}_{3}$}

Fig. 7 showed the variations of sludge floc size and fractal dimension $\left(\mathrm{D}_{\mathrm{F}}\right)$ after combined nano- $\mathrm{Fe}_{2} \mathrm{O}_{3}$ and TSC treatment. As can be seen in Fig. 7 (a), the flocs size with composite treatment was much larger than that under single $\mathrm{TSC}_{0.5}$ conditioning, indicating that particle aggregation was significantly improved by nano- $\mathrm{Fe}_{2} \mathrm{O}_{3}$ addition. The sludge flocs size obviously increased with the reaction time at low speed of mixing, while it sharply decreased with the fragmentation of flocs when the mixing speed was up to $400 \mathrm{rpm} / \mathrm{min}$. The floc size began to increase due to sludge flocs reflocculation after stirring speed was reduced to $40 \mathrm{rpm} / \mathrm{min}$.

It was interesting note that when the nano- $\mathrm{Fe}_{2} \mathrm{O}_{3}$ dosage was increased from 0.01 to $0.09 \mathrm{~g} / \mathrm{gTSS}$, equilibrium floc size of sludge conditioned with nano- $\mathrm{Fe}_{2} \mathrm{O}_{3}$ and $\mathrm{TSC}_{0.5}$ increased firstly and then reduced and reached the maximum at the dosage of $0.03 \mathrm{~g} / \mathrm{gTSS}$. As mentioned above, the $\mathrm{pH}$ was decreased to around 6.5 after $\mathrm{TSC}_{0.5}$ addition (see in Table $\mathrm{S} 1$ ), nano- $\mathrm{Fe}_{2} \mathrm{O}_{3}$ was positively charged at $\mathrm{pH}$ less than 7. Overdosed nano- $\mathrm{Fe}_{2} \mathrm{O}_{3}$ resulted in charge reversal and destabilization of sludge system, which was very likely to result in deterioration of sludge dewatering behavior. At the same time, from Fig. 7 (b), it should be noted that the sludge floc $D_{F}$ decreased at the stage of low mixing speed and increased at the process of high speed, which was in contrast to the sludge floc size. When the dosage of nano- $\mathrm{Fe}_{2} \mathrm{O}_{3}$ was $0.01 \mathrm{~g} / \mathrm{gTSS}$, the sludge floc $\mathrm{D}_{\mathrm{F}}$ firstly increased from 2.08 to 1.92 and then up to 2.07. These could be suggested that the structure of sludge flocs conditioned by composite nano- $\mathrm{Fe}_{2} \mathrm{O}_{3}$ and TSC became looser during the process of their aggregation, while it got into denser when the flocs were broken. In addition, Table 4 demonstrated that the strength and recovery factors of sludge floc were effectively enhanced by nano$\mathrm{Fe}_{2} \mathrm{O}_{3}$ addition, which could explain the decrease of sludge compressibility coefficients.

It was generally accepted that cake layer structure played a very crucial role in sludge filtration process, so the microstructure of sludge cake after vacuum filtration was observed by SEM. It can be seen from Fig. S1 that raw sludge cake showed a relative smooth surface. By comparison, the sludge cakes conditioned by different TSCs exhibited more plentiful tiny channels which were likely to
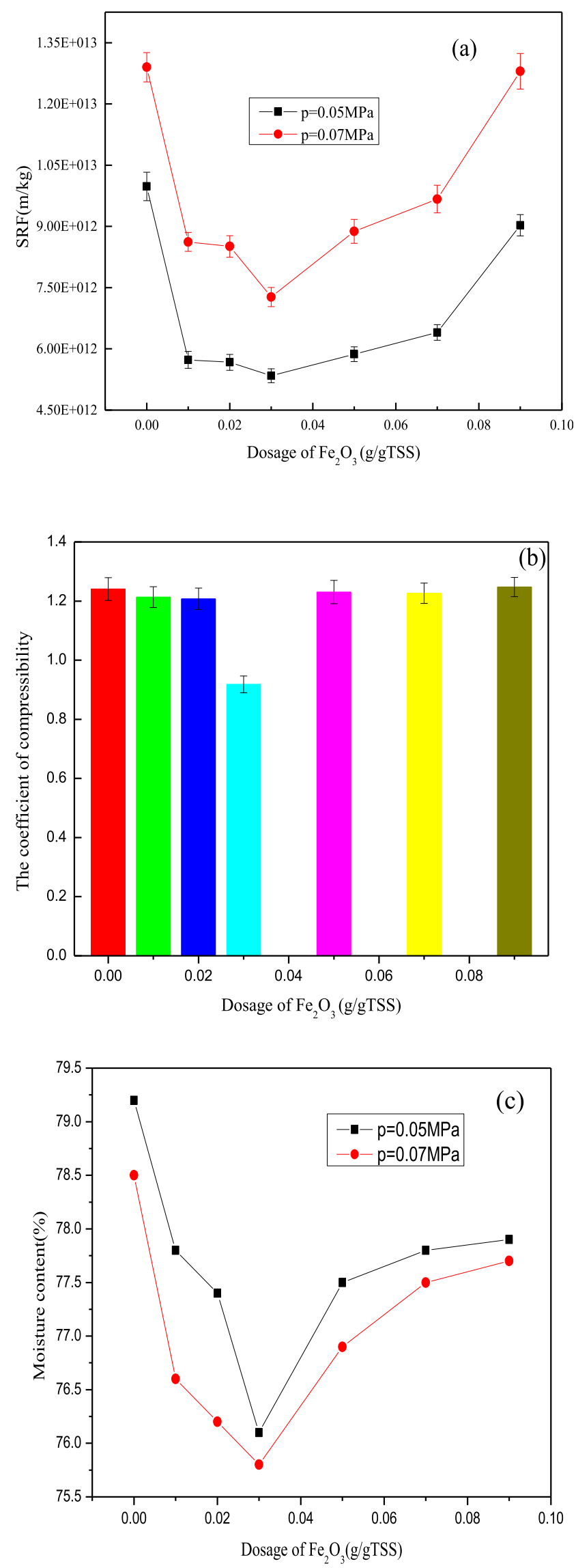

Fig. 6. Effects of combined conditioning with nano- $\mathrm{Fe}_{2} \mathrm{O}_{3}$ and $\mathrm{TSC}_{0.5}$ on sludge compressibility ( $\mathrm{TSC}_{0.5}$ dosage was 0.005 gTi/gTSS). 

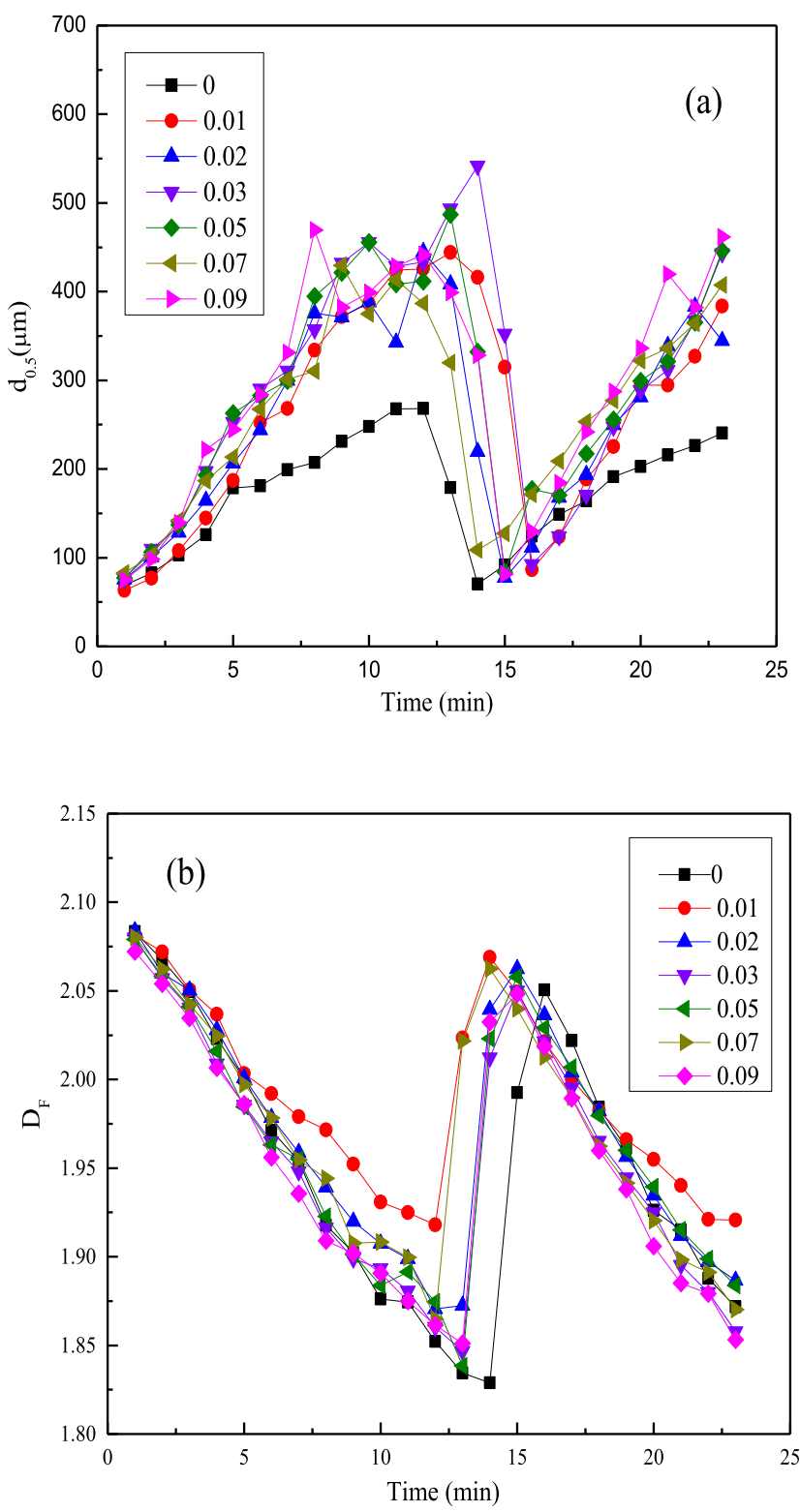

Fig. 7. Changes in particle size and $\mathrm{D}_{\mathrm{F}}$ of sludge flocs with time under chemical conditioning with combined nano $\mathrm{Fe}_{2} \mathrm{O}_{3}$ and $\mathrm{TSC}_{0.5}$.

Table 4

Strength and recovery factor of sludge floc formed conditioning by TSCs in combination with nano- $\mathrm{Fe}_{2} \mathrm{O}_{3}$.

\begin{tabular}{lll}
\hline Nano- $\mathrm{Fe}_{2} \mathrm{O}_{3}$ (g/gTSS) & $\mathrm{R}_{\mathrm{f}}(\%)$ & $\mathrm{S}_{\mathrm{f}}(\%)$ \\
\hline 0 & 0.903 & 0.437 \\
0.01 & 1.682 & 0.579 \\
0.02 & 1.044 & 0.327 \\
0.03 & 1.255 & 0.419 \\
0.05 & 1.158 & 0.334 \\
0.07 & 1.231 & 0.505 \\
0.09 & 1.113 & 0.323 \\
\hline
\end{tabular}

facilitate the water release under filtration dewatering. As mentioned above, since the sludge flocs formed by $\mathrm{TSC}_{0.5}$ conditioning were more rigid and resistant to compress, this phenomenon was more apparent for $\mathrm{TSC}_{0.5}$. Likewise, the sludge cake formed by $\mathrm{TSC}_{0.5}$ in combination with nano- $\mathrm{Fe}_{2} \mathrm{O}_{3}$ showed a similar structural properties to that of obtained from $\mathrm{TSC}_{0.5}$ treatment.

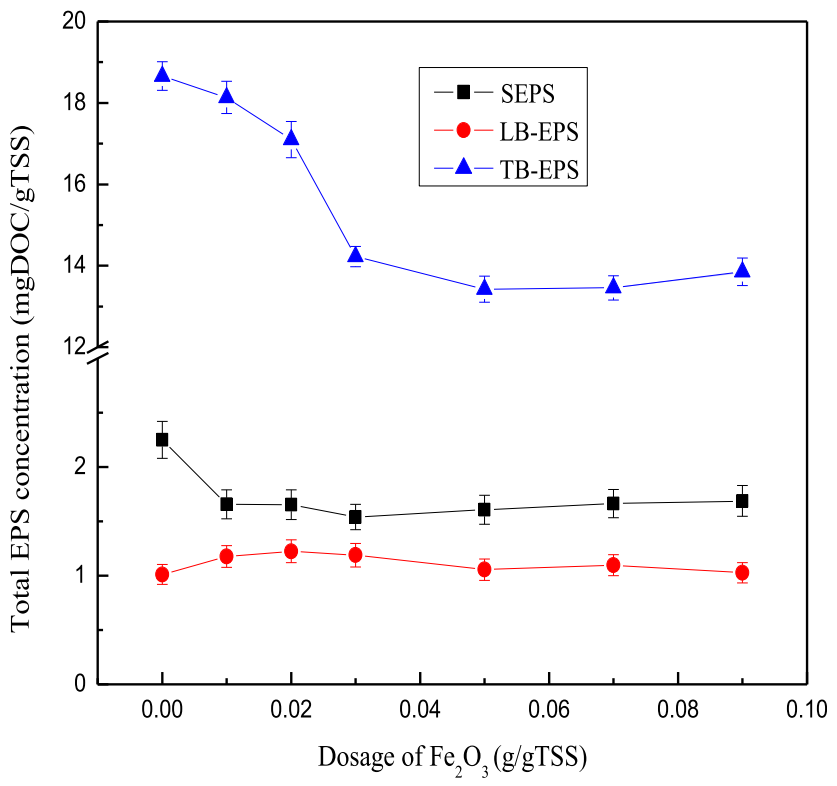

Fig. 8. Effects of nano- $\mathrm{Fe}_{2} \mathrm{O}_{3}$ dosage on concentrations of different EPS fractions under combined conditioning ( TSC $_{0.5}$ dosage was 0.005 gTi/gTSS).

\subsubsection{Effects of composite nano- $\mathrm{Fe}_{2} \mathrm{O}_{3}$ and $\mathrm{TSC}_{0.5}$ treatment on EPS distribution and composition}

Fig. 8 displayed the changes of organic matters in different sludge EPS fractions after nano- $\mathrm{Fe}_{2} \mathrm{O}_{3}$ and TSC addition. Both the content of SEPS and TB-EPS were reduced after nano $\mathrm{Fe}_{2} \mathrm{O}_{3}$ addition and reached the minimum at the dose of $0.03 \mathrm{~g} / \mathrm{gTSS}$, while no obvious change in LB-EPS was observed. This result was in agreement with SRF, the lower extractable EPS was always associated with stronger floc structure and better sludge dewatering property.

As presented in Table 5 and Fig. S3 (see in support information), no obvious change in chemical composition was detected, while fluorescent intensities of protein-like and humic substances were reduced after addition of nano- $\mathrm{Fe}_{2} \mathrm{O}_{3}$. It was reported that nano$\mathrm{Fe}_{2} \mathrm{O}_{3}$ could bind with protein-like substance and form complexes with biopolymers of high molecular weights through hydrophobic and electrostatic interactions (Treuel and Nienhaus, 2012).

The effects of combined nano $\mathrm{Fe}_{2} \mathrm{O}_{3}$ with TSC treatment on sludge MW Peak intensities and distribution were depicted in Fig. 9 and Fig. S5 respectively. Four MW peaks of 4000 Da, 3000 Da, 2000 Da and 1200 Da observed in SEPS component weakened significantly after nano $\mathrm{Fe}_{2} \mathrm{O}_{3}$ and TSC treatment. As for LB-EPS fraction, the peak of 60,000 Da was disappeared and at the same time, the intensities of $4000 \mathrm{Da}$ and $3000 \mathrm{Da}$ peaks obviously decreased. With increase of nano $\mathrm{Fe}_{2} \mathrm{O}_{3}$ addition, small molecular substance with MW distribution from 180 Da to 1000 Da gradually increased and it reached the maximum when the dosage of nano $\mathrm{Fe}_{2} \mathrm{O}_{3}$ was $0.03 \mathrm{~g} / \mathrm{gTSS}$.

\subsection{The economic evaluation of TSCS on sludge dewatering}

Compared with the traditional aluminum and iron salts, titanium salt is a new type of coagulants. Titanium is believed to be non-poisonous and had no adverse influence on the ecological environment. The market price of $\mathrm{TiCl}_{4}$ was 8000 yuan per ton, while that of the commonly used inorganic salts - polymeric aluminum chloride (PACl) was around 2000 yuan per ton. According to our study, the optimal dosages of TSCs and $\mathrm{PACl}$ were $0.003 \mathrm{gTi} / \mathrm{gTSS}$ and $0.05 \mathrm{gAl} / \mathrm{gTSS}$ for sludge conditioning respectively (Cao et al., 2016). The dosage of PACl is nearly ten times as 
Table 5

Effects of combined conditioning with TSC and $\mathrm{Fe}_{2} \mathrm{O}_{3}$ nano-particles on EPS fluorescent intensities.

\begin{tabular}{|c|c|c|c|c|c|}
\hline & \multirow[t]{2}{*}{ Dosage of $\mathrm{Fe}_{2} \mathrm{O}_{3} \mathrm{~g} / \mathrm{gTSS}$} & \multirow{2}{*}{$\frac{\text { Tryptopha protein }}{\lambda \text { ex/em }(280 / 335)}$} & \multirow{2}{*}{$\frac{\text { Aromatic protein }}{\lambda \text { ex/em }(230 / 330)}$} & \multirow{2}{*}{$\frac{\text { Fulvic acid }}{\lambda \text { ex/em }(275 / 455)}$} & \multirow{2}{*}{$\frac{\text { Humic acid }}{\lambda \text { ex/em }(350 / 420)}$} \\
\hline & & & & & \\
\hline \multirow[t]{6}{*}{ SEPS } & 0.01 & 65.26 & 12.69 & 16.61 & 15.17 \\
\hline & 0.02 & 75.37 & 23.94 & 14.96 & 11.77 \\
\hline & 0.03 & 97.17 & 27.84 & 17.28 & 18.66 \\
\hline & 0.05 & 112 & 37.85 & 18.56 & 19.95 \\
\hline & 0.07 & 99.72 & 48.48 & 19.12 & 16.16 \\
\hline & 0.09 & 79.88 & 26.64 & 12.22 & 19.32 \\
\hline \multirow[t]{6}{*}{ LB-EPS } & 0.01 & 71.60 & 43.6 & 15.43 & 14.97 \\
\hline & 0.02 & 110.4 & 57.44 & 15.74 & 14.81 \\
\hline & 0.03 & 148.9 & 80.64 & 25.36 & 20.71 \\
\hline & 0.05 & 144.2 & 76.26 & 24.04 & 20.89 \\
\hline & 0.07 & 200.4 & 115.2 & 48.59 & 26.13 \\
\hline & 0.09 & 236.5 & 132.7 & 60.31 & 32.07 \\
\hline \multirow[t]{6}{*}{ TB-EPS } & 0.01 & 614.66 & 314.3 & 74.35 & 21.66 \\
\hline & 0.02 & 598.6 & 299.9 & 93.48 & 29.16 \\
\hline & 0.03 & 645.7 & 346.7 & 71.91 & 24.65 \\
\hline & 0.05 & 588.4 & 260.6 & 96.13 & 23.96 \\
\hline & 0.07 & 642.90 & 322.4 & 67.44 & 20.04 \\
\hline & 0.09 & 673.7 & 315.6 & 82.38 & 21.31 \\
\hline
\end{tabular}

*SEPS samples were diluted by 10 times; LB-EPS and TB-EPS samples were diluted by 50 times.

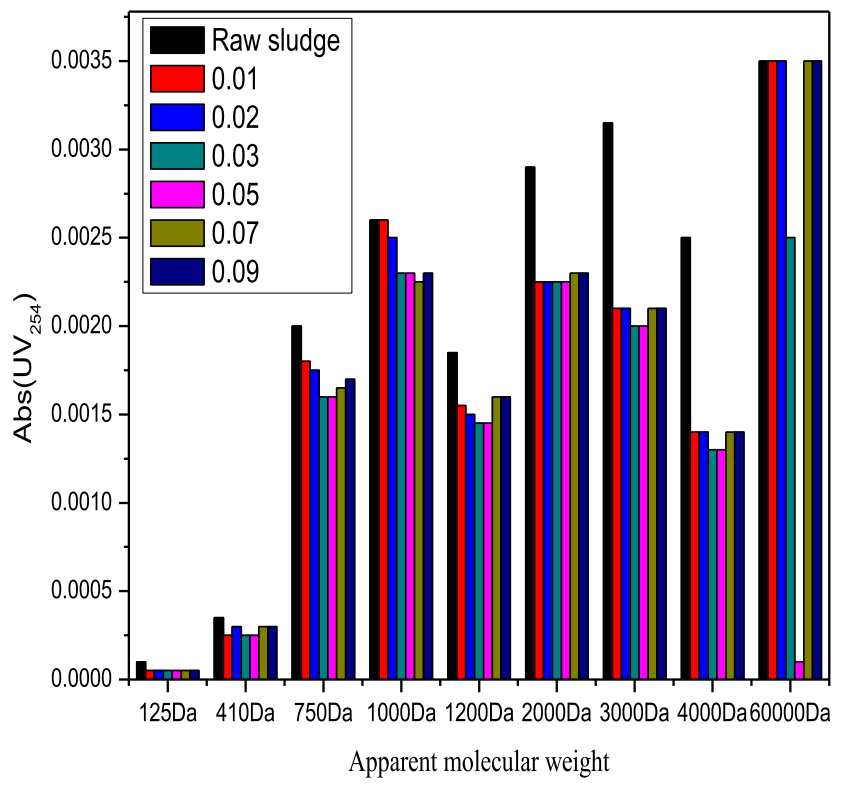

Fig. 9. Influence of chemical conditioning with nano- $\mathrm{Fe}_{2} \mathrm{O}_{3}$ in combination with $\mathrm{TSC}_{0.5}$ on organic substances with different molecular weights in SEPS fraction (Samples were diluted by 10 times)

much as that of titanium salt to achieve the same dewatering efficiency. Therefore, titanium salts conditioning was more economical than $\mathrm{PACl}$ in sludge treatment.

\section{Conclusions}

In this study, the effects of chemical conditioning using different TSCs in combination with magnetic nano- $\mathrm{Fe}_{2} \mathrm{O}_{3}$ on dewatering performance were evaluated, and the change in morphological and EPS properties was investigated to unravel the mechanisms involved under chemical conditioning.

- Waste activated sludge dewaterability was enhanced by using different TSCs treatment, and $\mathrm{TSC}_{0.5}$ was more effective in dewaterability improvement. Sludge floc formed with $\mathrm{TSC}_{0.5}$ treatment was characterized by larger floc size and higher floc strength than that conditioned by other TSCs.

- EPS compress was the major mechanism of sludge conditioning with TSCs, and $\mathrm{TSC}_{0.5}$ showed better performance in compressing EPS structure and removal of protein-like substances in SEPS fraction.

- Addition of $\mathrm{Fe}_{2} \mathrm{O}_{3}$ nanoparticles could further improve dewatering performance and decrease compressibility of sludge system by acting as skeleton builders to enhance floc strength. The particles aggregation was effectively improved with addition of nano- $\mathrm{Fe}_{2} \mathrm{O}_{3}$. The sludge flocs conditioned using TSCs in combination with nano- $\mathrm{Fe}_{2} \mathrm{O}_{3}$ were more resistant to break and more easily regrew after shearing.

\section{Acknowledgment}

This study was financially supported by National Natural Science Foundation of China (51338010, 51678546, 41630318, 21277130 and 51478445), National Natural Science Foundation of Hubei province in China (ZRMS2016000811) Chinese Universities Scientific Fund (CUG160824) and China Postdoctoral Science Foundation (2016M590733).

\section{Appendix A. Supplementary data}

Supplementary data related to this article can be found at http:// dx.doi.org/10.1016/j.watres.2016.12.011.

\section{References}

Apha, A., 1998. Wef. Standard Methods for the Examination of Water and Wastewater, twentieth ed. American Public Health Association, American Water Work Association, Water Environment federation, Washington DC. 252.

Biggs, C.A., Ford, A.M., Pa, L., 2001. Activated sludge flocculation: direct determination of the effect of calcium ions. Water Sci. Technol. A J. Int. Assoc. Water Pollut. Res. 43 (11), 75-82.

Booksh, K., Westerhoff, P., Leenheer, J.A., 2004. Fluorescence excitation - emission matrix regional integration to quantify spectra for dissolved organic matter. Environ. Sci. Technol. 37 (24), 5701-5710.

Cao, B., Zhang W. Wang Q, Huang Y, Meng C., Wang, D. 2016. Wastewater sludge dewaterability enhancement using hydroxyl aluminum conditioning: role of aluminum speciation. Water Res. 105, 615-624.

Chow, C.W.K., Fabris, R., van Leeuwen, J., Wang, D.S., Drikas, M., 2008. Assessing natural organic matter treatability using high performance size exclusion chromatography. Environ. Sci. Technol. 42 (17), 6683-6689.

Henderson, R.K., Baker, A., Murphy, K.R., Hambly, A., Stuetz, R.M., Khan, S.J., 2009. 
Fluorescence as a potential monitoring tool for recycled water systems: a review. Water Res. 43 (4), 863-881.

Higgins, M.J., Novak, J.T., 1997. The effect of cations on the settling and dewatering of activated sludges: laboratory results. Water Environ. Res. 69, 215.

Hongwei, Z., Ming, L.E.I., Ying, L.I., Xuehua, Z., Jie, W., 2008. Extraction of extracellular polymeric substances from activated sludge in membrane bioreactor. J. Chem. Ind. Eng. China 59 (6), 1531-1534.

Houghton, J.I., Quarmby, J., Stephenson, T., 2001. Municipal wastewater sludge dewaterability and the presence of microbial extracellular polymer. Water Sci. Technol. 44 (2-3), 373-379.

Jarvis, P., Jefferson, B., Parsons, S.A., 2005. Breakage, regrowth, and fractal nature of natural organic matter flocs. Environ. Sci. Technol. 39, 2307-2314.

Kim, J.-H., Cho, D., Kim, G.-J., Gao, B., Shon, H., 2011. Titania nanomaterials produced from Ti-Salt flocculated sludge in water treatment. Catal. Surv. Asia 15 (2), $117-126$.

Li, X.Y., Yang, S.F., 2007. Influence of loosely bound extracellular polymeric substances (EPS) on the flocculation, sedimentation and dewaterability of activated sludge. Water Res. 41 (5), 1022-1030.

Li, Y., Yuan, X., Wu, Z., Wang, H., Xiao, Z., Wu, Y., Chen, X., Zeng, G., 2016. Enhancing the sludge dewaterability by electrolysis/electrocoagulation combined with zero-valent iron activated persulfate process. Chem. Eng. J. 303, 636-645.

Liang, P., Bin, H.U., Jiang, Z.C., Qin, Y.C., 2004. Application of adsorbents in element speciation analysis. J. Anal. Sci. 20 (3), 322-326.

Liu, Y., Fang, H.H., 2003. Influences of extracellular polymeric substances (EPS) on flocculation, settling, and dewatering of activated sludge. Crit. Rev. Environ. Sci. Technol. 33 (3), 237-273.

Liu, Y.Y., Zhang, W.J., Yang, X.Y., Xiao, P., Wang, D.S., Song, Y., 2013. Advanced treatment of effluent from municipal WWTP with different metal salt coagulants: contaminants treatability and floc properties. Sep. Purif. Technol. 120, $123-128$.

Lyko, S., Al-Halbouni, D., Wintgens, T., Janot, A., Hollender, J., Dott, W., Melin, T., 2007. Polymeric compounds in activated sludge supernatant characterisation and retention mechanisms at a full-scale municipal membrane bioreactor. Water Res. 41 (17), 3894-3902.

Mikkelsen, L.H., Keiding, K., 2002. Physico-chemical characteristics of full scale sewage sludges with implications to dewatering. Water Res. 36 (10), $2451-2462$.

Murthy, S.N., Novak, J.T., 1999. Factors affecting floc properties during aerobic digestion: implications for dewatering. Water Environ. Res. 197-202.

Neyens, E., Baeyens, J., Dewil, R., De heyder, B., 2004. Advanced sludge treatment affects extracellular polymeric substances to improve activated sludge dewatering. J. Hazard. Mater. 106 (2-3), 83-92.

Niu, M., Zhang, W., Wang, D., Chen, Y., Chen, R., 2013. Correlation of physicochemical properties and sludge dewaterability under chemical conditioning using inorganic coagulants. Bioresour. Technol. 144, 337-343.

Qi, Y., Thapa, K.B., Hoadley, A.F.A., 2011. Application of filtration aids for improving sludge dewatering properties - a review. Chem. Eng. J. 171 (2), 373-384.

Sheng, G.P., Yu, H.Q., 2006. Characterization of extracellular polymeric substances of aerobic and anaerobic sludge using three-dimensional excitation and emission matrix fluorescence spectroscopy. Water Res. 40 (6), 1233-1239.

Shon, H.K., Vigneswaran, S., Kim, I.S., Cho, J., Kim, G.J., Kim, J.B., Kim, J.H., 2007. Preparation of titanium dioxide (TiO2) from sludge produced by titanium tetrachloride (TiCl4) flocculation of wastewater. Environ. Sci. Technol. 41 (4), 1372-1377.

Shon, H.K., Vigneswaran, S., Kandasamy, J., Kim, J.B., Park, H.J., Choi, S.W., Kim, J.H., 2009a. Preparation of titanium oxide, iron oxide, and aluminium oxide from sludge generated from Ti-salt, Fe-salt and Al-salt flocculation of wastewater. J. Ind. Eng. Chem. 15 (5), 719-723.

Shon, H.K., Vigneswaran, S., Kandasamy, J., Zareie, M.H., Kim, J.B., Cho, D.L., Kim, J.H., 2009b. Preparation and characterization of titanium dioxide $\left(\mathrm{TiO}_{2}\right)$ from sludge produced by TiCl4 flocculation with $\mathrm{FeCl}_{3}, \mathrm{Al}_{2}\left(\mathrm{SO}_{4}\right)_{3}$ and $\mathrm{Ca}(\mathrm{OH})_{2}$ coagulant aids in wastewater. Sep. Sci. Technol. 44 (7), 1525-1543.

Tomaszewska, M., Mozia, S., Morawski, A.W., 2004. Removal of organic matter by coagulation enhanced with adsorption on PAC. Desalination 161 (1), 79-87.

Treuel, L., Nienhaus, G.U., 2012. Toward a molecular understanding of nanoparticle-protein interactions. Biophys. Rev. 4 (2), 137-147.

Vaxelaire, J., Cézac, P., 2004. Moisture distribution in activated sludges: a review. Water Res. 38 (9), 2215-2230.

Wang, G.T., Li, J.Y., Tian, B.H., Liu, H., Liu, J.W., 2009a. Preparation of nano-sized iron oxide flocculant and the applied research. Environ. Eng. 27, 606-610 (in chinese).

Wang, Y., Gao, B.Y., Xu, X.M., Xu, W.Y., Xu, G.Y., 2009b. Characterization of floc size, strength and structure in various aluminum coagulants treatment. J. Colloid Interface Sci. 332 (2), 354-359.

Wang, D.S., Xing, L.N., Xie, J.K., Chow, C.W.K., Xu, Z.Z., Zhao, Y.M., Drikas, M., 2010. Application of advanced characterization techniques to assess DOM treatability of micro-polluted and un-polluted drinking source waters in China. Chemosphere 81 (1), 39-45.

Yu, G.H., He, P.J., Shao, L.M., He, P.P., 2008. Stratification structure of sludge flocs with implications to dewaterability. Environ. Sci. Technol. 42 (21), 7944-7949.

Zhang, W., Xiao, P., Liu, Y., Xu, S., Xiao, F., Wang, D., Chow, C.W., 2014a. Understanding the impact of chemical conditioning with inorganic polymer flocculants on soluble extracellular polymeric substances in relation to the sludge dewaterability. Sep. Purif. Technol. 132 (20), 430-437.

Zhang, W.J., Xiao, P., Liu, Y.Y., Xu, S.W., Xiao, F., Wang, D.S., Chow, C.W.K., 2014b, Understanding the impact of chemical conditioning with inorganic polymer flocculants on soluble extracellular polymeric substances in relation to the sludge dewaterability. Sep. Purif. Technol. 132, 430-437.

Zhang, W., Peng, S., Xiao, P., He, J., Yang, P., Xu, S., Wang, D., 2015a. Understanding the evolution of stratified extracellular polymeric substances in full-scale activated sludges in relation to dewaterability. RSC Adv. 5 (2), 1282-1294.

Zhang, W., Yang, P., Yang, X., Chen, Z., Wang, D., 2015b. Insights into the respective role of acidification and oxidation for enhancing anaerobic digested sludge dewatering performance with Fenton process. Bioresour. Technol. 181, 247-253.

Zhang, W.J., Peng, S.W., Xiao, P., He, J., Yang, P., Xu, S.W., Wang, D.S., 2015c. Understanding the evolution of stratified extracellular polymeric substances in full-scale activated sludges in relation to dewaterability. Rsc Adv. 5 (2), 1282-1294.

Zhang, W.J., Yang, P., Xiao, P., Xu, S.W., Liu, Y.Y., Liu, F., Wang, D.S., 2015d. Dynamic variation in physicochemical properties of activated sludge floc from different WWTPs and its influence on sludge dewaterability and settleability. Colloids Surfaces A Physicochem. Eng. Aspects 467, 124-134.

Zhao, Y.Q., Bache, D.H., 2001. Conditioning of alum sludge with polymer and gypsum. Colloids Surf. A 194, 213-220.

Zhao, Y.X., Gao, B.Y., Shon, H.K., Cao, B.C., Kim, J.H., 2011. Coagulation characteristics of titanium ( $\mathrm{Ti}$ ) salt coagulant compared with aluminum ( $\mathrm{Al}$ ) and iron (Fe) salts. J. Hazard. Mater. 185 (2-3), 1536-1542.

Zhao, Y., Phuntsho, S., Gao, B., Huang, X., Qi, Q., Yue, Q., Wang, Y., Kim, J.-H., Shon, H., 2013. Preparation and characterization of novel polytitanium tetrachloride coagulant for water purification. Environ. Sci. Technol. 47 (22), 12966-12975. 